\title{
Love, Joy and Delight!
}

\section{Paul Wilkins*}

NHS Research, UK

*Corresponding author: Paul Wilkins, NHS Research, 84 Rydal Avenue, Freckleton, $\mathrm{Nr}$ Preston, Lancs PR4 1DJ, UK, Tel: 01772 634542; Email: creativewriter@virginmedia.com

\section{Poetry}

Volume 1 Issue 1

Received Date: September 07, 2017

Published Date: September 11, 2017

DOI: $10.23880 / \mathrm{mhrij}-16000107$

Your mind and emotion hold the key

They're the things to set you free

What 'er the day

What 'er the night

Fulfill yourself with love, joy and delight

Sadness and worry

Gets you nowhere at all

Just up the wall

What 'er the day

What 'er the night

Fulfill yourself with love, joy and delight

With faith in the Lord

And determination

You may live a long and happy life

What 'er the day

What 'er the night

Fulfill yourself with love, joy and delight

Let people come first where 'er you go

That's a thought

All people should show

What 'er the day

What 'er the night

Fulfil yourself with love, joy and delight

Love, joy and delight

Love, joy and delight

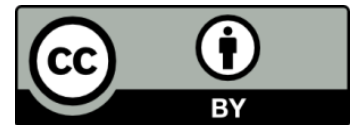

